\title{
Chemotaxis of Actinoplanes missouriensis Zoospores to Fungal Conidia, Chlamydospores and Sclerotia
}

\author{
By DILIP K. ARORA \\ Laboratory of Microbial Ecology, Department of Botany, Banaras Hindu University, \\ Varanasi 221005 , India
}

(Received 13 August 1985; revised 4 December 1985)

\begin{abstract}
The chemotactic response of Actinoplanes missouriensis zoospores to three different types of fungal spores (conidia of Curvularia lunata, chlamydospores of Fusarium solani and sclerotia of Macrophomina phaseolina) and their exudates was examined in vitro and in soil. Zoospores were attracted in vitro to substances exuded by fungal spores and to a number of organic compounds but not to sodium phosphate buffer solution. Numbers of zoospores attracted to spores of $C$. lunata, $F$. solani or $M$. phaseolina and their exudates, mixed in a sterilized soil, were significantly $(P=0.05)$ greater than to soil only supplemented with buffer. Movement of zoospores in an unsterilized soil to conidia, chlamydospores or sclerotia was significantly greater $(P=0.05)$ than background populations occurring in soil held at $0,-10$ and -50 mbar matric potential. Attraction of zoospores to fungal spores and (or) their exudates was generally in the order of conidia $>$ chlamydospores $>$ sclerotia both in vitro and in soil. The results suggest that compounds exuded by living fungal spores may act as attractant for motile Actinoplanes zoospores.
\end{abstract}

\section{INTRODUCTION}

The genetics and biochemistry of chemotaxis and motility of bacteria have been extensively investigated (Adler, 1975; Macnab, 1979). Much work has also been done on chemotaxis as a mechanism for attraction of rhizobia to the legume rhizosphere (Schmidt, 1979; Dazzo, 1980). However, there is little information about the chemotactic response of motile micro-organisms to motile or non-motile microbes in natural habitats. Fungi appear to play a role in bacterial movement and growth in soil, through hyphae serving as migration pathways and spore exudates as growth substances (Lockwood, 1968; Siala \& Gray, 1974; Wong \& Griffin, 1976b). Cell wall components of Pythium ultimum acted as an attractant for Pseudomonas spp. (Chet $e t$ al., 1971) and Bacillus pumilus was attracted towards the conidia of Cladosporium cladosporioides (Diem, 1975). Arora et al. (1983b) demonstrated that Erwinia herbicola, Pseudomonas fluorescens and $P$. putida were strongly attracted in vitro and in soil to the substances exuded by conidia of Cochliobolus sativus and sclerotia of Macrophomina phaseolina.

Members of the genus Actinoplanes are zoosporic actinomycetes (Bland \& Couch, 1981). The role of these micro-organisms in soil ecology is uncertain. The chemotactic response of Actinoplanes strains to some inorganic compounds containing chloride and bromide has been investigated by Palleroni (1976). Recently, species of Actinoplanes were reported to be hyperparasites of some soil-borne fungal resting structures and considered as potential biological control agents (Sneh et al., 1977; Sutherland, 1982). However, virtually nothing is known about the chemotactic responses of Actinoplanes zoospores to various types of fungal spores and their exudates though the motile phase of these micro-organisms gives the opportunity for migration and thus plays a significant role in the search for a suitable host.

The object of this work is to contribute towards the understanding of the chemotactic response of Actinoplanes missouriensis zoospores to the conidia of Curvularia lunata, chlamydospores of Fusarium solani and sclerotia of Macrophomina phaseolina in vitro and in soil. 


\section{METHODS}

Actinoplanes. A. missouriensis Couch (obtained from J. L. Lockwood, Michigan State University, USA) was grown on Czapek's sucrose/nitrate agar (CSA) (Cohn, 1921) made with soil water at $28^{\circ} \mathrm{C}$ under laboratory light $\left(20 \mu \mathrm{E} \mathrm{m}^{-2} \mathrm{~s}^{-1}\right)$. Zoospores were released by flooding 20-25-d-old culture plates for 40 min with $10 \mathrm{ml}$ sterile 50 mM-sodium phosphate buffer ( $\mathrm{pH} 7.0$ ) containing $0 \cdot 1 \%(\mathrm{v} / \mathrm{v})$ Tween-80 (Higgins et al., 1967). Cultures were gently scraped with a sterile wire loop to disrupt the mature sporangia. Zoospores were washed by centrifugation at $10000 \mathrm{~g}$ for $10 \mathrm{~min}$ at $5^{\circ} \mathrm{C}$, using aseptic procedures, and filtered through a Nuclepore membrane filter $(0.2 \mu \mathrm{m}$ pore size). The membrane bearing washed zoospores was resuspended in $10 \mathrm{ml}$ sterile buffer ( $\mathrm{pH} 7 \cdot 0$ ). The number of motile zoospores was established microscopically and by plating diluted zoospores suspension in CSA medium.

${ }^{14} \mathrm{C}$-Labelled cultures of $\boldsymbol{A}$. missouriensis were grown on CSA medium (15 ml per plate) containing $12 \mu \mathrm{Ci}{ }^{14} \mathrm{C}$ labelled glucose (specific activity $225 \mathrm{mCi} \mathrm{mmol}^{-1} ; 8.3 \mathrm{GBq} \mathrm{mmol}^{-1}$ ). Zoospores were harvested as described earlier.

Fungi. Isolates of Curvularia lunata (Walker) Bodijn, Fusarium solani (Martius) App. \& Wollen. and Macrophomina phaseolina (Mablanc) Ashby were maintained on potato dextrose agar. Conidia of $C$. lunata, chlamydospores of $F$. solani and sclerotia of $M$. phaseolina were obtained as described elsewhere (Arora $e t$ al., 1983a; Hsu \& Lockwood, 1973). Exudates from 3-5-week-old cultures of fungal spores were prepared by incubating washed spores in $50 \mathrm{~mm}$-buffer solution at $25^{\circ} \mathrm{C}$ for a period less than that required for germination $(6-$ $8 \mathrm{~h}$ for conidia, $12-16 \mathrm{~h}$ for chlamydospores and sclerotia). Exudate was filtered through sterile membranes $\left(0.45 \mu \mathrm{m}\right.$ pore size) and stored at $4{ }^{\circ} \mathrm{C}$ until use.

Chemotaxis in vitro. The capillary-tube assay was used to measure chemotaxis of motile zoospores of $A$. missouriensis towards exudate of conidia, chlamydospores or sclerotia (Arora et al., $1983 \mathrm{a}$ ). A $0.5 \mathrm{~cm}$ i.d. (internal diameter $) \times 2 \mathrm{~cm}$ long glass tube was cemented near one end, parallel to the long axis, of a glass slide $(7.5 \times$ $2.5 \mathrm{~cm})$. Disposable glass capillaries $(1 \mu \mathrm{l}, 3 \mathrm{~cm}$ long; Drummand Scientific Co.) were filled with different concentrations of exudate of fungal spores (Fig. 1) or $10^{-2} \mathrm{M}$ concentration of some organic carbon nutrients (Table 1). Glass chambers were filled with zoospores of $A$. missouriensis $\left(2-3 \times 10^{7}\right.$ zoospores $\left.\mathrm{ml}^{-1}\right)$ suspended in buffer solution ( $\mathrm{pH} \mathrm{7.0)}$. The open end of a capillary was inserted into the chamber containing motile zoospores and assays were done after $60 \mathrm{~min}$ at $30^{\circ} \mathrm{C}$. Control capillaries contained only buffer solution and were used to determine the background motility of zoospores. After incubation, capillaries were removed and crushed in $10 \mathrm{ml}$ $0.85 \% \mathrm{NaCl}$ solution. Diluted suspension was plated on CSA medium. Mean numbers of zoospores in triplicate assays were determined. The results were expressed as a ratio of zoospore number in capillaries containing attractant to those in capillaries containing buffer (relative response).

Chemotaxis in sterilized soil. A sandy loam soil was used (pH $6.9 ; 2.1 \%$ organic matter, $71.2 \%$ sand, $14.5 \%$ silt and $12.0 \%$ clay). Before use, the soil was sieved ( $2 \mathrm{~mm}$ mesh) and stored moist at $5{ }^{\circ} \mathrm{C}$ until use. It was sterilized by autoclaving at $103.5 \mathrm{kPa}$ for $20 \mathrm{~min}$. Washed latex tubes $(0.25 \mathrm{~cm}$ i.d. $\times 1 \mathrm{~cm}$ long), sealed at one end, were autoclaved and packed with $0.135 \mathrm{~g}$ soil. The soil was either (i) saturated with $50 \mathrm{mM}$-sodium phosphate buffer

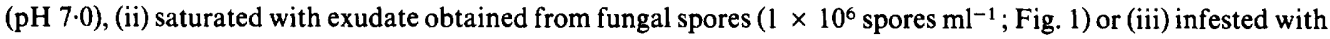
$1 \times 10^{5}$ conidia, $1 \times 10^{4}$ chlamydospores or $1 \times 10^{4}$ sclerotia. Infested soil in (iii) was allowed to equilibrate aseptically for $2 \mathrm{~h}$ before use. The open end of each tube was placed in $0.4 \mathrm{ml}$ zoospore suspension of $A$. missouriensis $\left(2-3 \times 10^{7}\right.$ zoospores $\left.\mathrm{ml}^{-1}\right)$ or in buffer held within the glass chambers of a chemotaxis apparatus (Arora et al., 1983a). Tubes were incubated for $60 \mathrm{~min}$ at $30^{\circ} \mathrm{C}$. Zoospores attracted in the soil were estimated by the dilution plate technique.

Chemotaxis in unsterilized soil. The chemotactic response of zoospores to fungal spores was measured at different soil matric potentials by a tension plate method (Duniway, 1976). In brief, soil $(50 \mathrm{~g})$ was placed in incubation chambers made from $200 \mathrm{ml}$ glass Buchner funnels with fritted glass discs ( $4.5 \mu \mathrm{m}$ porosity) as a tension plate. By adjusting the height of the tension plate relative to a water reservoir, the matric potential of the soil in the chamber was adjusted to $0,-10,-50,-100$ and -200 mbar.

Water agar blocks (Difco) about $8 \mathrm{~mm}$ long $\times 2 \mathrm{~mm}$ diam were rolled over the conidia of $C$. lunata, chlamydospores of $F$. solani or sclerotia of $M$. phaseolina. Approximately, 4-5 $\times 10^{7}$ conidia, 4-5 $\times 10^{5}$ chlamydospores and $3 \times 10^{6}$ sclerotia adhered to the surface of the agar blocks. The number of spores adhering to the agar blocks was determined by haemocytometer counts. Agar blocks containing fungal spores were gently placed on soil in Buchner funnels (10 per funnel). In control treatments, agar blocks were without fungal spores. A suspension of motile ${ }^{14} \mathrm{C}$-labelled zoospores $\left(0.35 \mathrm{ml}\right.$ containing $2 \times 10^{8}$ zoospores) was placed over the soil surface with a microsyringe, care being taken that zoospores should not splash or run across the soil surface. The distance between the applied suspension of zoospores and the blocks containing fungal spores was approximately $4,8,12$ and $16 \mathrm{~mm}$. Before placing the suspension of zoospores, the soil was equilibrated for $48 \mathrm{~h}$ at $0,-10$ and -50 mbar matric potential. After $60 \mathrm{~min}$, agar blocks were placed in scintillation vials (one block per vial) and crushed into several small pieces. Scintillation cocktail (Long, 1976) (10 ml) was added to each vial and counts were corrected using a $\left[{ }^{14} \mathrm{C}\right]$ toluene standard (Filonow \& Lockwood, 1983). Radioactivity present in the fungal spores was measured in a liquid scintillation spectrometer. 

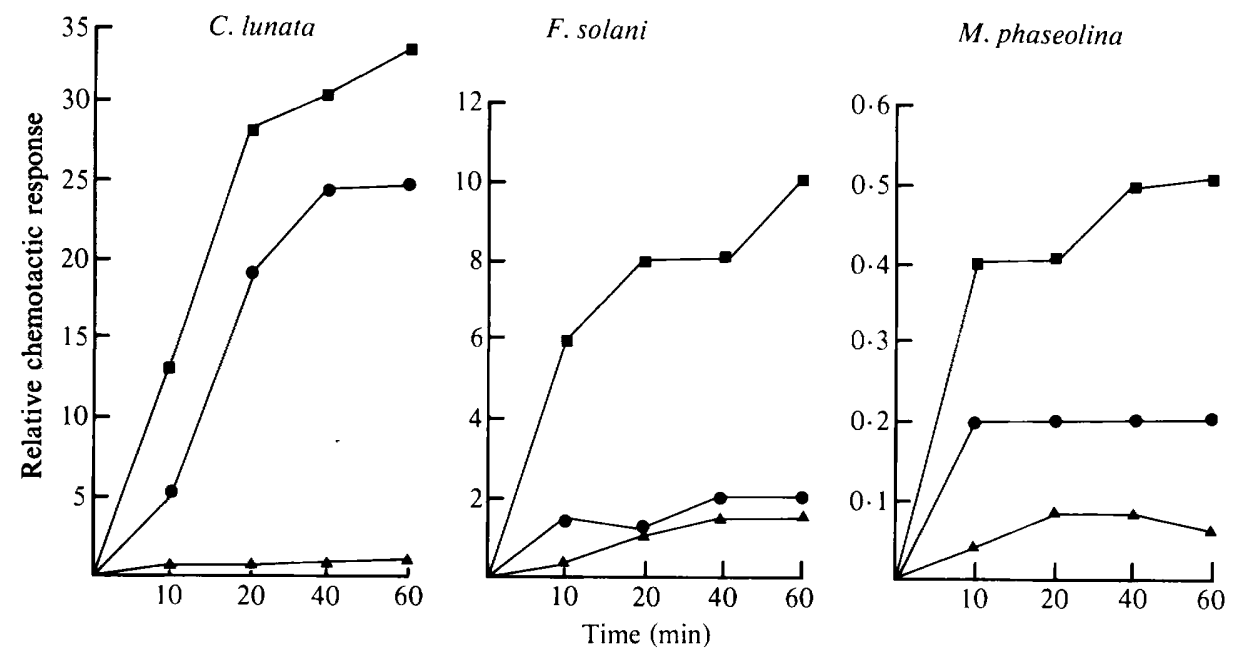

Fig. 1. Relative chemotactic response of $A$. missouriensis zoospores to the exudates of fungal spores. Different numbers of fungal spores $\mathrm{ml}^{-1}$ were used to prepare the exudate; $\mathbf{\Delta}, 1 \times 10^{4} ; \mathbf{O}, 1 \times 10^{6} ; \mathbf{\square}$, $1 \times 10^{8}$. Data are means of three replicates.

All experiments were repeated one or more times to establish reproducibility. Data were subjected to analysis of variance or Student's $t$ test. For analysis of variance, differences between means were distinguished by Duncan's multiple range test.

\section{RESULTS}

Accumulation of zoospores in response to exudate $\left(1 \times 10^{8}\right.$ fungal spores $\left.\mathrm{ml}^{-1}\right)$ was directly related to the length of incubation period (Fig. 1). In all cases, attraction of zoospores was linear until 40-60 min of incubation, except in capillaries containing exudate of $C$. lunata $\left(1 \times 10^{4}\right.$ conidia $\left.\mathrm{ml}^{-1}\right)$ and $F$. solani $\left(1 \times 10^{4}\right.$ chlamydospores $\left.\mathrm{ml}^{-1}\right)$ where a linear increase was observed after a lag of $10 \mathrm{~min}$. Different responses of zoospores were observed between three concentrations of exudate of conidia, chlamydospores or sclerotia. For example, capillaries filled with the three different concentrations of $C$. lunata conidia attracted respectively $0.6 \times$ $10^{5}, 11.6 \times 10^{5}$ and $16.7 \times 10^{5}$ zoospores after $60 \mathrm{~min}$ incubation whereas capillaries filled with buffer contained $0.5 \times 10^{5}$ zoospores. Generally, capillaries containing higher concentrations of exudate resulted in greater accumulation of zoospores. The relative accumulation of zoospores in response to exudate was greater in the order conidia $>$ chlamydospores $>$ sclerotia. In contrast to bacteria (Adler, 1967), no peculiar migratory bands were seen in the capillaries filled with exudate or organic carbon nutrients.

Chemotaxis of zoospores to some organic carbon nutrients was examined and their relative accumulation in the capillaries is given in Table 1 . All the nutrients significantly $(P=0.05)$ attracted the zoospores (except rhamnose and trehalose) compared with buffer. The relative response of zoospores to glucose, mannitol and maltose was highest, as they respectively exhibited 28-, 16- and 13-fold greater accumulation than that of capillaries filled with buffer.

Zoospores were attracted in sterilized soil supplemented with fungal spores or exudate (Table 2). Accumulation of zoospores was not significantly greater in soil mixed with $C$. lunata conidia or $F$. solani chlamydospores than with their exudates. The movement of zoospores in sterilized soil mixed with fungal spores or exudate was three- to fourfold greater than in soil saturated with buffer.

Varying extents of zoospore movement in unsterilized soil were attained at various soil matric potentials by placing conidia, chlamydospores or sclerotia at different distances from a source of ${ }^{14} \mathrm{C}$-labelled motile zoospores (Fig. 2). Labelled zoospores exhibited maximum movement 
Table 1. Chemotaxis of $A$. missouriensis zoospores to some carbon nutrients

Zoospore concentrations in the chamber were $3 \times 10^{7} \mathrm{ml}^{-1}$. Accumulation of zoospores was recorded after $60 \mathrm{~min}$. Sealed capillaries were filled with $10^{-2} \mathrm{M}$ concentration of nutrient. Data are means of six replicates; values followed by the same letter are not significantly different $(P=0.05)$ by Duncan's multiple range test.

$\begin{array}{lc}\begin{array}{l}\text { Attractant in } \\ \text { capillaries }\end{array} & \begin{array}{c}10^{-4} \times \text { No. of zoospores } \mathrm{ml}^{-1} \\ \text { attracted in capillaries }\end{array} \\ \text { Buffer } & 0 \cdot 2^{a} \\ \text { Rhamnose } & 0 \cdot 6^{b} \\ \text { Trehalose } & 0 \cdot 9^{b} \\ \text { Galactose } & 1 \cdot 1^{c} \\ \beta \text {-D-Fructose } & 1 \cdot 9^{d} \\ \text { Maltose } & 2 \cdot 7^{e} \\ \text { Mannitol } & 3 \cdot 2^{f} \\ \text { D-Glucose } & 5 \cdot 6^{g}\end{array}$

Table 2. Chemotaxis of A. missouriensis zoospores in sterilized soil containing fungal spores or their exudates

Accumulation of zoospores was recorded after $60 \mathrm{~min}$. Data are means of three replicates; values followed by the same letter are not significantly different $(P=0.05)$ by Duncan's multiple range test.

\begin{tabular}{lccc}
\multicolumn{1}{c}{ Attractant } & \multicolumn{1}{c}{$10^{-3} \times$ No. of zoospores per g soil } \\
\cline { 2 - 4 } C. lunata & F. solani & $M$. phaseolina \\
Soil + fungal spores & $16^{a}$ & $11^{a}$ & $9^{a}$ \\
Soil + fungal exudate & $20^{a}$ & $13^{a}$ & $16^{b}$ \\
Soil + buffer & $5^{b}$ & $3^{b}$ & $3^{c}$
\end{tabular}

towards conidia, less towards chlamydospores and least towards sclerotia. This type of response is similar to that observed in vitro. In general, movement of zoospores was recorded from distances of 4 to $8 \mathrm{~mm}$ at $0,-10$ and -50 mbar matric potential. The response of zoospores to fungal spores in soil was not significantly different to that of controls at -100 and -200 mbar matric potential. Movement of zoospores was significantly less at all matric potentials at distances greater than $8 \mathrm{~mm}$ from the source of motile zoospores. Therefore, zoospore motility in soil was influenced by (1) soil matric potentials, (2) different types of fungal spores used and (3) distances between zoospores and fungal spores.

\section{DISCUSSION}

The results show that exudate from different types of fungal spores can attract motile zoospores of $A$. missouriensis. The differential chemotactic response of zoospores to the spores suggested differences in chemical stimuli and signals for each of the spore types. The nature and relative amounts of nutrients exuded by the three very different types of spores were not determined. However, compounds exuded could have been derived, in part at least, from energy reserves of the fungal spores and thus may consist of many monosaccharides, sugar alcohols, amino acids and amino sugars (Epstein \& Lockwood, 1983; A. B. Filonow \& J. L. Lockwood, unpublished results). In addition to qualitative differences in exudate, exudation rates of spores may differ, thereby influencing zoospore motility. Thin-walled conidia may exude more than thick-walled conidia and relatively metabolically inactive chlamydospores and sclerotia. Filonow \& Lockwood (1983) observed that the ${ }^{14} \mathrm{C}$ exudation rate in soil from thin-walled conidia of Cochliobolus sativus was greater than that from thick-walled sclerotia of $M$. phaseolina. My results are consistent with the above views because attraction of zoospores to conidial exudate was much higher than to that of chlamydospores or sclerotia. 


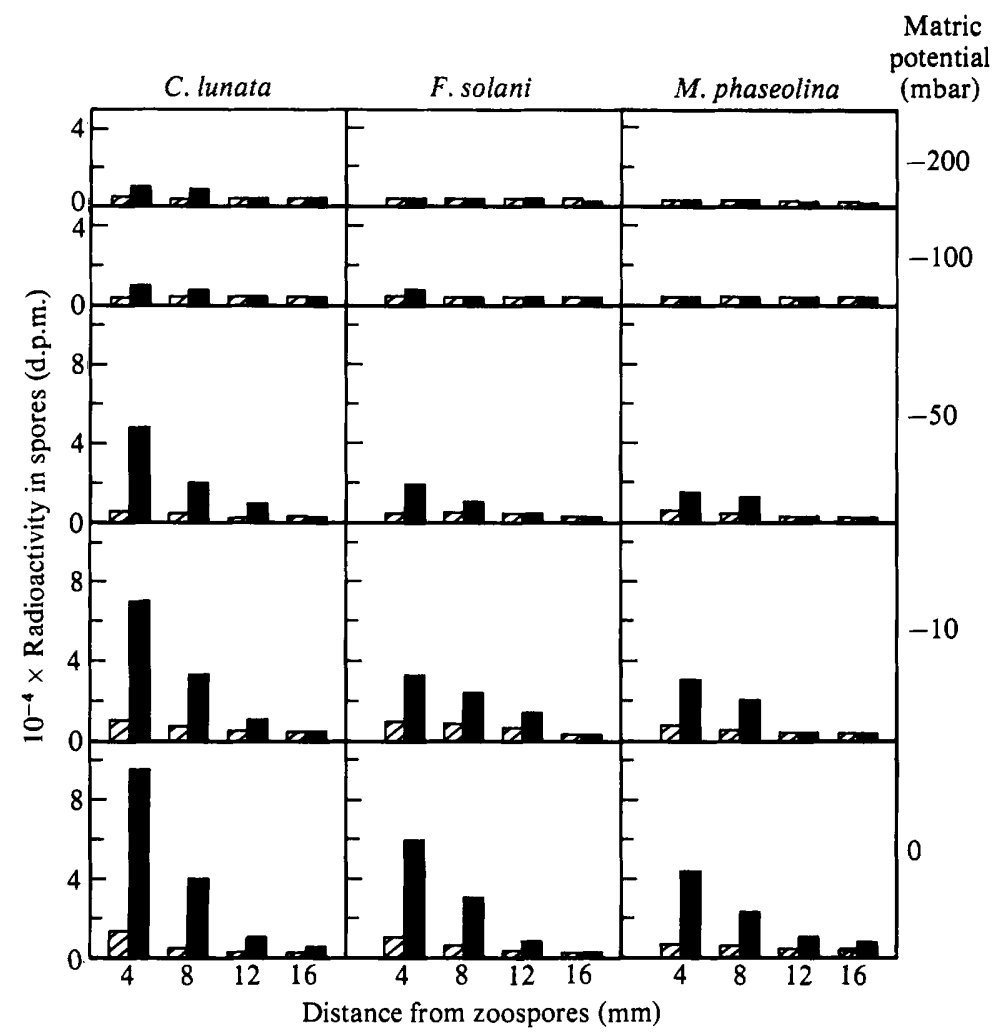

Fig. 2. Chemotactic response of $A$. missouriensis zoospores to fungal spores in soil at different soil water matric potentials. $\square$, Control; $\square$, means of three replicates. All values differed significantly from the control $(P=0.05$, Student's $t$ test) except values at matric potentials of -100 and -200 mbar when fungal spores were placed 12 and $16 \mathrm{~mm}$ from motile zoospores.

Contrary to my results, Palleroni (1976) showed chemotactic response of several Actinoplanes species to halides but not to a number of organic compounds. Chemotaxis of motile microorganisms to organic carbon or energy sources may be independent of the capacity of such compounds to serve as carbon or energy sources (Adler, 1969). Palleroni (1976) reported no chemotaxis of Actinoplanes brasiliensis zoospores towards several growth substances despite the use of these substrates by $A$. brasiliensis. In this study, utilization of ${ }^{14} \mathrm{C}$-labelled exudate from labelled fungal spores or ${ }^{14} \mathrm{C}$-labelled glucose by $A$. missouriensis was observed (results not shown).

After chemotaxis, zoospores of $A$. missouriensis may become established around the sporosphere of fungal spores or its immediate neighbourhood and, as a result of this, fungistasis may occur. An association between enhanced exudation and germination repression of fungal spores in soil or in model systems imposing energy stress has been demonstrated (Arora et al., $1983 b$; Lockwood \& Filonow, 1983). In the present study a significant relationship between enhanced exudation and germination repression was not found when zoospores were incubated for $60 \mathrm{~min}$ in the presence of ${ }^{14} \mathrm{C}$-labelled conidia, chlamydospores or sclerotia (unpublished results). Thus, it is tempting to speculate that Actinoplanes zoospores situated in the sporosphere of fungal spores might not have the capacity to establish fungistasis.

Like the motility of bacteria, motility of Actinoplanes zoospores would also be expected to vary with soil colloids (Goring \& Hamker, 1972), soil moisture content (Wong \& Griffin, 1976a) and the diameter and continuity of soil pores (Hamadi, 1971). Invariably, soil at a matric potential of 0 and -10 mbar was most suitable for active movement of zoospores. Like the zoospores of 
Phytophthora cryptogea (Duniway, 1976), zoospores of $A$. missouriensis apparently require higher matric potentials for active movement in soil than do nematodes (Jones, 1975) and bacteria (Griffin, 1972; Hamadi, 1971).

Sneh et al. (1977) reported parasitism of oospores of Phytophthora megasperma var. sojae, P. cactorum, Pythium sp. and Aphanomyces euteiches by $A$. missouriensis in soil held at water saturation. Parasitism of oospores of $P$. megasperma var. sojae by $A$. missouriensis was greater $(82 \%)$ at 0 mbar than at lower matric potentials (Sutherland, 1982). Thus, chemotaxis at a matric potential sufficient to permit the movement of zoospores might play a significant role in the colonization of fungal resting structures in soil, which may be subsequently parasitized. Destruction of these thick-walled sexually produced fungal spores by Actinoplanes may result in reduced disease potential.

Although these results provide information that $A$. missouriensis zoospores can be attracted to the different types of fungal spores in soil, much additional work is needed before the actual role of Actinoplanes chemotaxis in soil ecology can be ascertained.

I am indebted to Professor J. L. Lockwood, Department of Botany and Plant Pathology, Michigan State University, USA, for encouraging me to work in the present line of research and reading the manuscript. I thank Dr Bharat Rai for reading the revised manuscript.

\section{REFERENCES}

ADLER, J. (1967). A method for measuring chemotaxis and use of the methods to determine optimum condition for chemotaxis by Escherichia coli. Journal of General Microbiology 74, 77-91.

ADLER, J. (1969). Chemoreceptors in bacteria. Science 166, 1588-1597.

ADLer, J. (1975). Chemotaxis in bacteria. Annual Review of Biochemistry 44, 341-356.

Arora, D. K., Filonow, A. B. \& Lockwood, J. L. (1983a). Bacterial chemotaxis to fungal propagules in vitro and in soil. Canadian Journal of Microbiology 29, 1104-1109.

Arora, D. K., Filonow, A. B. \& Lockwood, J. L. $(1983 b)$. Exudation from ${ }^{14} \mathrm{C}$-labelled fungal propagules in the presence of specific microorganisms. Canadian Journal of Microbiology 29, 1487-1492.

Bland, C. E. \& Couch, J. N. (1981). The family Actinoplanaceae. In Prokaryotes: Handbook on Habitats, Isolation and Identification of Bacteria, pp. 20042010. Edited by M. P. Starr, H. Stolp, H. G. Trüper, A. Balows \& H. G. S. Schlegel. New York: Springer Verlag.

Chet, I., Fogel, S. \& Mitchell, R. (1971). Chemical detection of microbial prey by bacterial predators. Journal of Bacteriology 106, 863-867.

CoHN, H. J. (1921). The use of various culture media in characterising actinomycetes. Bulletin of the New York State Agricultural Experiment Station no. 83.

DAzzo, F. B. (1980). Absorption of microorganisms to roots and other plant surfaces. In Absorption of Microorganisms to Surfaces, pp. 253-316. Edited by J. Witton \& K. Marshall. New York: John Wiley \& Sons.

DiEM, H. G. (1975). Attraction et repulsion des bactéries par les spores de Cladosporium cladosporioides en cours de germination. Canadian Journal of Botany 53, 1092-1096.

Duniway, J. M. (1976). Movement of zoospores of Phytophthora cryptogea in soils of various textures and matric potentials. Phytopathology 66, 877882 .
EPSTEIN, L. \& Lockwood, J. L. (1983). The role of exudation in the germination of Cochliobolus victoriae conidia. Journal of General Microbiology 129, 3629-3635.

Filonow, A. B. \& Lockwood, J. L. (1983). Mycostasis in relation to the microbial nutrient sinks of five soils. Soil Biology and Biochemistry 15, 557-565.

Goring, C. A. \& HamkeR, J. W. (1972). Organic Chemicals in the Soil Environment. Vol. II. New York: Marcel Dekker.

Griffin, D. M. (1972). Ecology of Soil Fungi, p. 193. Syracuse, New York: Syracuse University Press.

HAMADI, Y. A. (1971). Soil water tension and the movement of rhizobia. Soil Biology and Biochemistry 3, $121-126$.

Higgins, M. L., Lechevalier, M. P. \& Lechevalier, H. A. (1967). Flagellated actinomycetes. Journal of Bacteriology 63, 1446-1451.

Hsu, S. C. \& Lockwood, J. L. (1973). Chlamydospore formation in Fusarium in sterile salt solutions. Phytopathology 63, 597-602.

JONES, F. G. W. (1975). The soil as an environment for plant parasitic nematodes. Annals of Applied Biology 79, 113-139.

Lockwood, J. L. (1968). The fungal environment of soil bacteria. In The Ecology of Soil Bacteria, pp. 4465. Edited by T. R. G. Gray \& D. Parkinson. Liverpool: Liverpool University Press.

Lockwood, J. L. \& Filonow, A. B. (1983). Responses of fungi to nutrient limiting conditions and to inhibitory substances in natural habitats. In $A d$ vances in Microbial Ecology, vol. 5, pp. 1-61. Edited by $M$. Alexander. New York: Plenum Publishing Corporation.

LoNG, E. C. (1976). Selective aspects of sample handling in liquid scintillation counting. In Beckman Biochemical Technical Report, pp. 1-47. Fullerton, Calif.: Beckman Instrument Inc.

MACNAB, R. M. (1979). Bacterial motility and chemotaxis: the molecular biology of a behavioural system. CRC Critical Reviews in Biochemistry 5, 291-341. 
Palleroni, N. J. (1976). Chemotaxis in Actinoplanes. Archives of Microbiology 110, 13-18.

SchmidT, E. L. (1979). Initiation of plant root-microbe interactions. Annual Review of Microbiology 33, 335376.

Siala, A. \& Gray, T. R. G. (1974). Growth of Bacillus subtilis and spore germination in soil observed by a fluorescent antibody technique. Journal of General Microbiology 81, 191-198.

SNeH, B., Humble, S. J. \& Lockwood, J. L. (1977). Parasitism of oospores of Phytophthora megasperma var. sojae, $P$. cactorum, Pythium sp. and Aphanomyces euteiches in soil by oomycetes, chyteridomycetes, hypomycetes, actinomycetes and bacteria. Phytopathology 67, 622-628.

SUTHERLAND, E. (1982). Hyperparasites of oospores of Phytophthora megasperma var. sojae; host range, environmental parameters, and biological control. $\mathrm{PhD}$ thesis, Michigan State University, USA.

WonG, P. T. \& Griffin, D. M. (1976a). Bacterial movement at higher matric potentials I. In artificial and natural soils. Soil Biology and Biochemistry 8 , 215-218.

WONG, P. T. \& Griffin, D. M. (1976b). Bacterial movement at higher matric potentials II. In fungal colonies. Soil Biology and Biochemistry 8, 219-223. 